\title{
Factors Influencing Rootability of Dracaena Cuttings
}

Fatma Alzahra K. Attia ; I.H. El-Sallami*; M.M. Gad and Abudl-Hafeez, E.Y. Ornamental plants and Landscape gardening Dep. Fac. of Agri., Assiut University.

"E-mail: ismail.ahmed1@agr.au.edu.eg

\section{Abstract:}

Dracaena marginata, Lam. Cuttings (tip, middle and basal) were treated with certain growth regulators (IAA,IBA and NAA), each applied individually at $1000 \mathrm{ppm}$ as a powder, beside control treatment to define the most effective combination of auxin and cutting types stimulating the rootability.

The highest percentage of rooted cuttings was resulted from IBA (73\%) followed by IAA (46\%) and NAA (32\%). Tip-shoot cuttings showed the maximum rooting percentage $(46 \%)$, while basal cuttings resulted in the minimum rooting percentage, however, middle cuttings appeared intermediate responses. Also, IBA produced higher number and shorter roots than IAA. Similarly, basal cuttings produced the highest root number and formed the shortest roots.

Generally, tip-shoot cuttings treated with IBA $1000 \mathrm{ppm}$ proved to be more effective treatment enhancing the rooting percentage (88\%) and improving root characteristics.

Keywords: Propagation, Dracaena marginata, Rooting, IAA, IBA, NAA, Cutting type.

Received on: $22 / 3 / 2015$

Referees: Prof. Gamal T. Mousa
Accepted for publication on: 8/4/2015

Prof. Azza A. Tawfeek 